\title{
Effect of intramammary infusion of chitosan hydrogels at drying-off on bovine mammary gland involution
}

\author{
S. Lanctôt, ${ }^{*}$ P. Fustier, † A. R. Taherian,† B. Bisakowski, † X. Zhao, ${ }^{*}$ and P. Lacasse ${ }^{1}$ \\ *Department of Animal Science, McGill University, Sainte-Anne-de-Bellevue, Quebec, Canada H9X 3V9 \\ †Saint-Hyacinthe Research and Development Centre, Agriculture and Agri-Food Canada, Saint-Hyacinthe, Quebec, Canada J2S 8E3 \\ $\ddagger$ Sherbrooke Research and Development Centre, Agriculture and Agri-Food Canada, Sherbrooke, Quebec, Canada J1M 0C8
}

\section{ABSTRACT}

The transition from lactation to the dry period in dairy cows is a period of high risk for acquiring new intramammary infections. This risk is reduced when the involution of the mammary gland is completed. Accordingly, approaches that speed up the involution process after drying-off could reduce the incidence of mastitis. The current study aimed to develop a biological response modifier that could be injected into cow teats to promote immune cell migration and speed up involution. Chitosan, a natural polysaccharide derived from chitin, is able to trigger host innate immunity. We developed 2 formulations made from either high- or low-viscosity chitosan. Both are liquid at room temperature but form a hydrogel at body temperature. In the first experiment, each udder quarter of 7 Holstein cows in late lactation was randomly assigned at dryingoff to receive one of the following intramammary infusions: 2.5 or $5 \mathrm{~mL}$ of $5 \%$ (wt/vol) low-viscosity chitosan hydrogel, $5 \mathrm{~mL}$ of $5 \%$ high-viscosity chitosan hydrogel, or $5 \mathrm{~mL}$ of water. Milk (mammary secretion) samples were collected from each quarter on $\mathrm{d}-4,-1$ (dryingoff), 1, 3, 5, 7, and 10. Milk somatic cell counts and the concentrations of involution markers such as BSA, lactate dehydrogenase, and lactoferrin were measured in each sample. In comparison with the control, the chitosan hydrogel infusions significantly hastened the increases in somatic cell counts, BSA and lactoferrin concentrations, and lactate dehydrogenase activity in mammary secretions. No major differences between sources or volumes of chitosan were observed for the measured parameters. The compatibility of this approach with an internal teat sealant was verified in the second experiment. Each udder quarter of 8 Holstein cows was randomly assigned at drying-off to receive one of the following intramammary infusions: $5 \mathrm{~mL}$ of $2 \%$ low-viscosity chitosan hydrogel, $4 \mathrm{~g}$ of an internal

Received September 30, 2016

Accepted November 26, 2016.

${ }^{1}$ Corresponding author: Pierre.Lacasse@agr.gc.ca teat sealant, a combination of sealant and chitosan, or $5 \mathrm{~mL}$ of water. Milk (mammary secretion) samples were collected from each quarter on $\mathrm{d}-4,-1$ (drying-off), 5 , and 10 to measure involution markers. These results suggest that chitosan hydrogel infusion hastened mammary gland involution and activate immune response, which may reduce the risk of acquiring new intramammary infections during the drying-off period. Those results were not affected by the presence of the teat sealant, showing that both approaches are fully compatible and could be used in combination.

Key words: mastitis, involution, immunity, chitosan, dairy cow

\section{INTRODUCTION}

The lactation cycle of a dairy cow must include a dry period for optimal milk production in the following lactation (Andersen et al., 2005). Although milking cessation is essential for proper cell renewal, during early involution the cow mammary gland is vulnerable to new IMI (Smith et al., 1985; Leelahapongsathon et al., 2016). Even though milking is stopped, highyielding cows still secrete a significant amount of milk. The pressure buildup causes milk to leak and impairs keratin formation (Dingwell et al., 2004). Once the teat canal is open, microorganisms gain access to the mammary gland and cause infection (Cousins et al., 1980). Moreover, during early involution, the level of antibacterial components and concentration of immune cells in the milk secretions are minimal (Sordillo et al., 1987). Finally, high fat, casein, and lactose concentrations favor bacterial growth and interfere with the phagocytosis capacity of immune cells (Sordillo and Nickerson, 1988). Therefore, implementing an efficient mastitis prevention program during this period is crucial.

An important element of many mastitis control programs is the treatment of all cows with antibiotics at the end of lactation, regardless of the cows' infection status (Berry and Hillerton, 2002). Although this method aims to cure existing infections and prevent new IMI during the dry period, it is not equally ef- 
fective against all pathogens (Oliver et al., 2011). The major concern, perhaps, is consumer perception. As a result, Germany and the Netherlands have prohibited the prophylactic use of antibiotics in livestock, such that only cows with IMI can be treated (Swinkels et al., 2015). Consequently, the need is increasing for effective nonantibiotic IMI prevention treatments. Internal teat sealants could provide alternatives to dry-cow therapy. However, despite their benefits, the inert bismuth-based preparations are not totally effective (Krömker et al., 2014). Another proposed alternative to blanket dry-cow therapy is external teat-dipping regimens using iodinebased teat dips at drying-off. Despite their effectiveness in tiestall herds, these regimens are labor intensive and difficult to implement in freestall operations (Whist et al., 2006).

When early involution of the mammary gland is completed, the risk of acquiring a new IMI is minimal (Tatarczuch et al., 2002). Consequently, Oliver and Smith (1982) proposed that accelerating the involution process after drying-off could enhance the resistance of the mammary gland to new IMI during early involution. This acceleration can be achieved by using a biological response modifier (BRM; Tzianabos, 2000). However, the effect of the BRM tested so far are of short duration (Shamay et al., 2003; Dallard et al., 2010). Chitosan is a natural biocompatible polysaccharide derived by the partial deacetylation of chitin, which is the second most abundant polysaccharide in nature after cellulose (Rinaudo, 2006). Chitosan can be formulated to be injectable at room temperature but form a biodegradable hydrogel at body temperature (Chenite et al., 2000). Chitosan exhibits various biological properties. It has been used for drug formulation over the past $20 \mathrm{yr}$. Moreover, chitosan has bacteriostatic, bioadhesive, and bioactive properties (Şenel and McClure, 2004).

After drying-off, the permeability of tight junctions between epithelial cells increases, which allows paracellular transport between the interstitial space and milk (Nguyen and Neville, 1998). This transport can be assessed by measuring concentration of serum albumin and immunoglobulin in milk secretions (Hurley, 1989). Furthermore, the regression of mammary secretory tissue is accompanied by changes in milk secretion composition that occur gradually during early involution (Oliver and Sordillo, 1989). For instance, epithelial cells produce more lactoferrin as involution progresses (Capuco and Akers, 1999). Accordingly, milk secretion concentration of those markers is used to assess mammary gland involution progress.

The present study aimed to develop a chitosan-based BRM formulation that could be injected into the cow teat to promote sustained immune cell migration and hasten involution at drying-off. In addition, the effect of combining the chitosan-based BRM with an internal teat sealant was evaluated.

\section{MATERIALS AND METHODS}

\section{Preparation of Treatments}

All treatments were prepared with aseptic, nonpyrogenic products and materials under a laminar flow hood. For each concentration of chitosan $(2 \%$ and $5 \%$ wt/vol), a 200-mL solution was made by adding 120 $\mathrm{mL}$ of nonpyrogenic water $(<0.005$ endotoxin units/ $\mathrm{mL}$; Lonza, Walkersville, MD) to preweighed chitosan. The solution was agitated at $200 \mathrm{rpm}$ with a metal mixing rod. The $\mathrm{pH}$ of the solution was reduced to 3 via the addition of $0.1 \mathrm{M} \mathrm{HCl}$ (Sigma-Aldrich Co., St. Louis, $\mathrm{MO})$. The preparation was kept overnight at room temperature for complete hydration. The following day, the preparation $\mathrm{pH}$ was brought up to 6.8 using a $50 \%$ (wt/vol) $\beta$-glycerophosphate disodium salt hydrate (Sigma-Aldrich Co.) solution. Then, the volume was adjusted to $200 \mathrm{~mL}$ by the addition of nonpyrogenic water (Lonza). Finally, plastic syringes were filled with the desired volume, sealed with a cap, and stored at room temperature. We developed 2 formulations, using either high-viscosity (130-cP) or low-viscosity (90-cP) chitosan provided by Qingdao Yuda Century Economy and Trade Co. (Shibei District, Qingdao, China).

\section{Animals and Experimental Design}

The experiments were conducted in accordance with the guidelines of the Canadian Council on Animal Care (1993). The cows were housed in individual tie stalls at Agriculture and Agri-Food Canada's Sherbrooke Research and Development Centre (Sherbrooke, QC, Canada).

Experiment 1. Seven Holstein cows in late lactation $(319 \pm 29$ DIM at drying off; \pm SEM $)$ producing more than $15 \mathrm{~kg}$ (average $22.6 \pm 1.9$ ) of milk per day were used. Cows were milked twice a day and projected or real 305-d milk production was $9312 \pm 749 \mathrm{~kg}$. The group of cows was dried off at the same time, $90 \pm$ $17 \mathrm{~d}$ before the expected calving date. Prior to dry-off (d -4), quarter SCC averaged 122,693 $\pm 34,520$ cell/ $\mathrm{mL}$. Until dry-off, the cows were fed ad libitum a latelactation diet. After drying off, the cows were fed ad libitum a dry period diet and dry hay. Water was available ad libitum during the whole experiment.

At drying-off, each udder quarter was randomly assigned to 1 of 4 intramammary infusions, as follows: 5 $\mathrm{mL}$ of nonpyrogenic water (Lonza; $\mathrm{n}=7$ ), $2.5 \mathrm{~mL}$ of $5 \%$ (wt/vol) low-viscosity chitosan solution (LV2.5; n 
$=7$ ), $5 \mathrm{~mL}$ of $5 \%$ low-viscosity chitosan solution (LV5; $\mathrm{n}=7$ ), or $5 \mathrm{~mL}$ of $5 \%$ high-viscosity chitosan solution (HV5; n = 7). Before the infusions, the teats were compressed at the top to keep the infused preparation in the teat.

Milk samples (200 mL) were manually collected aseptically (National Mastitis Council, 1996) from each quarter just before the morning milking on $\mathrm{d}-4$ relative to drying-off as well as just before the last milking before drying-off $(\mathrm{d}-1)$. Mammary secretions from each quarter $(100 \mathrm{~mL})$ were manually collected aseptically on d $1,3,5,7$, and 10 after the last milking. The samples were used to measure SCC, the proportion of somatic cell types, and bacterial counts. Skim milk and somatic cells were separated by centrifugation $(1,000$ $\left.\times g, 4^{\circ} \mathrm{C}, 20 \mathrm{~min}\right)$. Skim milk aliquots were stored at $-20^{\circ} \mathrm{C}$ until determination of BSA concentration, lactate dehydrogenase (LDH) activity, and lactoferrin concentration. Pelleted somatic cells were washed with $10 \mathrm{~mL}$ of PBS (Mediatech, Manassas, VA) and centrifuged $\left(500 \times g, 4^{\circ} \mathrm{C}, 10 \mathrm{~min}\right)$. The PBS was discarded, and the cell pellet was suspended in $250 \mu \mathrm{L}$ of PBS. The samples were then stabilized in $1 \mathrm{~mL}$ of RNAlater (Sigma-Aldrich Co.) and stored at $-80^{\circ} \mathrm{C}$ until RNA extraction.

Experiment 2. Eight Holstein cows in late lactation (328 \pm 17 DIM at drying off) producing more than $15 \mathrm{~kg}$ (average $20.5 \pm 1.1$ ) of milk per day were used. Cows were milked twice a day and projected or real 305 -d milk production was $10,881 \pm 1,359 \mathrm{~kg}$. The group of cow was dried off at the same time, $62 \pm 4 \mathrm{~d}$ before expected calving date. Prior to dry-off (d -4$)$, quarter SCC averaged 87,654 $\pm 23,287$ cells $/ \mathrm{mL}$.

At drying-off, each udder quarter was randomly assigned to 1 of 4 intramammary infusions, as follows: 5 $\mathrm{mL}$ of nonpyrogenic water (Lonza; $\mathrm{n}=8$ ), $5 \mathrm{~mL}$ of $2 \%$ (wt/vol) low-viscosity chitosan solution $(\mathrm{n}=8), 4 \mathrm{~g}$ of Orbeseal teat sealant solution (Zoetis, Kirkland, QC, Canada; $\mathrm{n}=8$ ), or $4 \mathrm{~g}$ of Orbeseal teat sealant solution followed by $5 \mathrm{~mL}$ of $2 \%$ low-viscosity chitosan solution $(\mathrm{n}=8)$.

Milk samples $(200 \mathrm{~mL})$ on $\mathrm{d}-4$ and -1 and mammary secretions on d 5 and 10 were collected, prepared, and stored as described for experiment 1.

\section{Animal Evaluation}

In both experiments, the quarters were assessed for inflammation symptoms every $2 \mathrm{~h}$ for the first $12 \mathrm{~h}$ after the infusions and then 3 times per day $(0900,1300$, and $1900 \mathrm{~h}$ ) for the following $7 \mathrm{~d}$. Inflammation was scored from 1 to 6 according to the mammary gland chart created by Rambeaud et al. (2003), as follows: 1
$=$ normal, $2=$ slight swelling, $3=$ moderate swelling, $4=$ severe swelling, $5=$ scar tissue, and $6=$ edema. Rectal temperature was determined at the same time.

\section{SCC in Milk and Mammary Secretions}

Somatic cell counts were determined from fresh whole milk samples and mammary secretion samples using an automatic cell counter (DeLaval International AB, Tumba, Sweden). Samples of mammary secretions were diluted with commercial microfiltered skim milk until the SCC obtained was between 100 and 200 cells/ $\mu \mathrm{L}$.

\section{Identification of Somatic Cells by Flow Cytometry}

Seven-color immunophenotyping of somatic cells was performed on samples collected on $\mathrm{d}-1$ and 1 of experiment 1 and on $\mathrm{d}-1$ and 5 of experiment 2. Milk samples $(20 \mathrm{~mL})$ were diluted with $20 \mathrm{~mL}$ of PBS $1 \times$ and centrifuged $\left(1,000 \times g, 23^{\circ} \mathrm{C}, 15 \mathrm{~min}\right)$. The supernatant was removed, and the pellet was resuspended in 15 $\mathrm{mL}$ of washing buffer consisting of PBS $1 \times+1 \%$ BSA (Sigma-Aldrich Co.) $+2 \%$ normal goat serum (Meridian Life Sciences, Memphis, TN). The mixture was then centrifuged $\left(500 \times g, 4^{\circ} \mathrm{C}, 10 \mathrm{~min}\right)$. Cell washing was repeated with $25 \mathrm{~mL}$ of washing buffer until no more fat could be observed. Washing buffer was added to the cell pellet to reach a concentration of approximately 1 $\times 10^{7}$ somatic cells $/ \mathrm{mL}$. A control pool was made with $100 \mu \mathrm{L}$ from each sample. A $100-\mu \mathrm{L}$ volume from each sample and the pool were transferred into a 96-well round bottom plate. The plate was centrifuged (300 $\times g, 4^{\circ} \mathrm{C}, 5 \mathrm{~min}$ ), and the supernatant was removed. The cells were suspended with $100 \mu \mathrm{L}$ of washing buffer containing the primary antibodies listed in Table 1. The plate was incubated on ice in the dark for 25 min. The cells were then washed 3 times with washing buffer. The plate was centrifuged $\left(300 \times g, 4^{\circ} \mathrm{C}, 3 \mathrm{~min}\right)$, and the cells were resuspended with $100 \mu \mathrm{L}$ of washing buffer containing the secondary antibodies mix (Table 1). The plate was incubated again on ice in the dark for $25 \mathrm{~min}$, and the cells were washed 3 times. The cells were resuspended in $200 \mu \mathrm{L}$ of washing buffer.

The samples were analyzed immediately on a BD FACSCanto II flow cytometer (BD Biosciences, Mississauga, ON, Canada) equipped with 3 lasers in a 4-2-2 configuration. The BD FACSDiva version 8.0.1 operating software (BD Biosciences) was used for data acquisition and data analysis. The proportion of each somatic cell type was determined using distinctive receptors found on granulocytes, monocytes, and lymphocytes (Table 1). Then, subclasses of T-lymphocytes and non-T-lymphocytes were assessed by using other 
LANCTÔT ET AL.

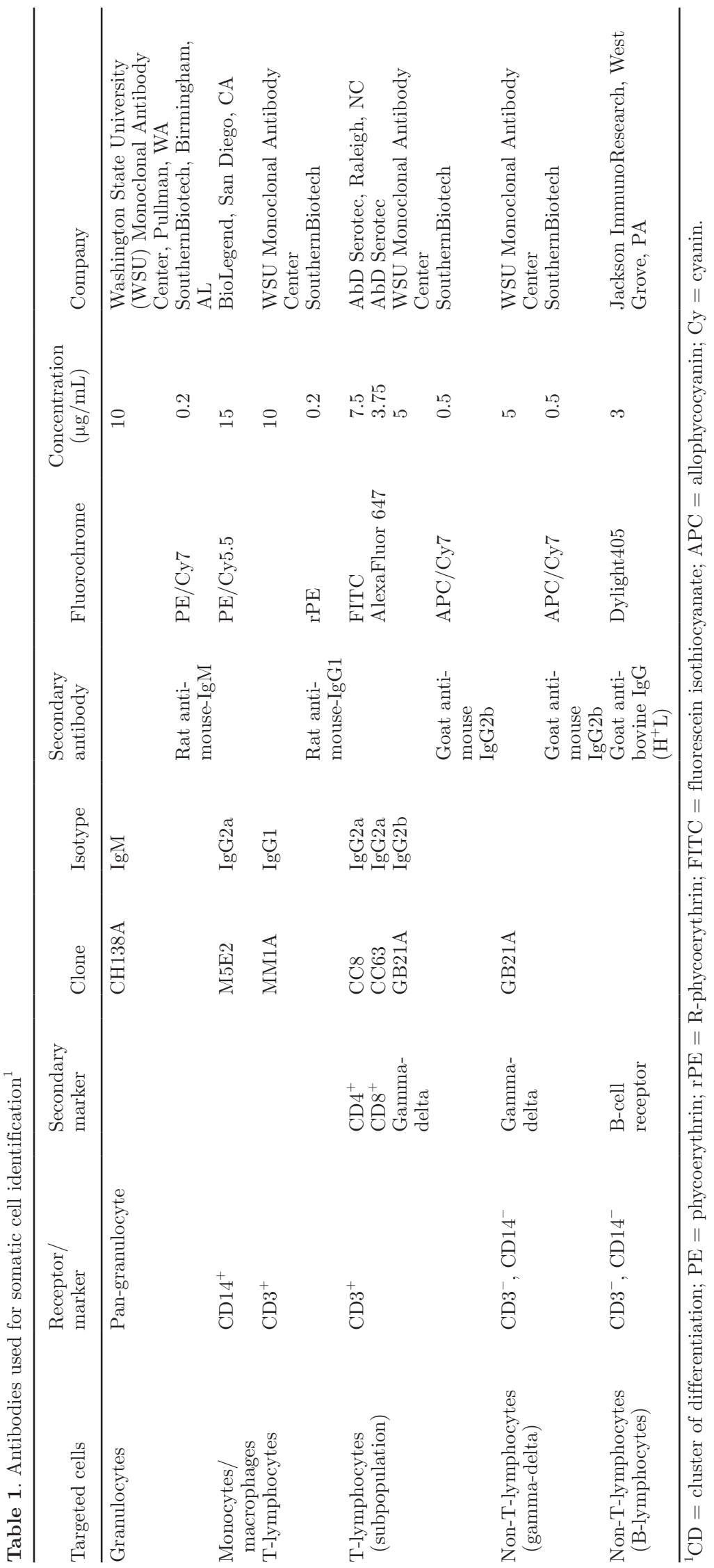


specific receptors. During the design of the experiment, fluorescent probes were selected to minimize the amount of fluorescence compensation to be done inside the different types of cells analyzed. Before the beginning of the experiment, each primary antibody was titered and tested for cross-reactivity with secondary antibodies. None of the primary antibodies showed cross-reactions or unspecific binding of secondary antibodies. Finally, a single-stain marker and Full Minus One cocktail were used to determine all gates.

\section{Bacterial Count Determination in Milk and Mammary Secretions}

For bacterial count determination, milk and mammary secretion samples were plated just after collection on tryptic soy agar, mannitol salt agar, and MacConkey II agar (Becton, Dickinson and Company, Mississauga, ON, Canada). The plates were then incubated at $37^{\circ} \mathrm{C}$ for $24 \mathrm{~h}$ before colonies were counted. Cow udder quarters infected with pathogens were excluded from the experiment. Accordingly, on experiment 1, data from one quarter treated with $2.5 \mathrm{~mL}$ of $5 \%$ low-viscosity chitosan solution were not used on d 5, 7, and 10 .

\section{BSA Concentration in Milk and Mammary Secretions}

The concentration of BSA in milk and mammary secretion samples was evaluated by a colorimetric assay as previously described by Bouchard et al. (1999), with some modifications. Briefly, $200 \mu \mathrm{L}$ of a skim milk sample was mixed with $450 \mu \mathrm{L}$ of water and $450 \mu \mathrm{L}$ of a solution containing 1 volume of $1.2 \mathrm{~m} M$ bromocresol green dissolved in $5 \mathrm{mM} \mathrm{NaOH}, 3$ volumes of $0.2 M$ succinic acid ( $\mathrm{pH} 4.0$ ), and $0.8 \%$ Brij-35 detergent. The sample was then mixed by inversion and centrifuged at room temperature $(1,900 \times g, 10 \mathrm{~min})$. The optical density of the supernatant was read at $640 \mathrm{~nm}$ using a SpectraMax 250 microplate reader (Molecular Devices, Sunnydale, CA). For experiment 1, the intra- and interassay coefficients of variation were 4.6 and $7.6 \%$, respectively. For experiment 2, the intra- and interassay coefficients of variation were 1.1 and $3.1 \%$, respectively.

\section{LDH Activity in Milk and Mammary Secretions}

The LDH assay was performed using the CytoTox 96 Non-Radioactive Cytotoxicity Assay kit (Promega, Madison, WI) according to the manufacturer's instructions. For experiment 1, the intra- and interassay coefficients of variation were 1.8 and $3.5 \%$, respectively. For experiment 2 , the intra- and interassay coefficients of variation were 2.3 and $4.8 \%$, respectively.

\section{Lactoferrin Concentration in Milk and Mammary Secretions}

The concentration of lactoferrin in the skim milk and mammary secretions was measured by ELISA using a commercial bovine lactoferrin ELISA quantitation set (Bethyl Laboratories Inc., Montgomery, TX). For experiment 1 , the intra- and interassay coefficients of variation were 4.6 and $5.9 \%$, respectively. For experiment 2 , intra- and interassay coefficients of variation were 4.5 and $6.3 \%$, respectively.

\section{Real-Time PCR}

Total RNA was extracted from somatic cells $\left(-80^{\circ} \mathrm{C}\right.$ samples) using the PureLink RNA Mini Kit and TRIzol RNA isolation reagents (Life Technologies, Carlsbad, CA) according to the manufacturer's instructions. The extraction process included on-column digestion with PureLink DNase (Life Technologies) to eliminate possible DNA contamination. The concentration and purity of the RNA were evaluated by spectrophotometric analysis using an ND-1000 spectrophotometer (NanoDrop Technologies Inc., Wilmington, DE), and RNA integrity was assessed with an Agilent 2100 Bioanalyzer system (Agilent Technologies, Waldbronn, Germany) using an Agilent RNA 600 Nano kit (Agilent Technologies) according to the manufacturer's instructions. Samples containing less than $31.25 \mathrm{ng} / \mu \mathrm{L}$ were concentrated with RNA Clean \& Concentrator-5 (Zymo Research, Irvine, CA) according to the manufacturer's protocol. Reverse transcription was performed using TransScript First-Strand cDNA Synthesis Super Mix (TransGen Biotech, Beijing, China) according to the manufacturer's protocol. From the resulting cDNA, $3.5 \mu \mathrm{L}$ of each sample was used to make a pool (116 samples from this study). The remaining cDNA was diluted 1:15 in water. A mixture of $3 \mu \mathrm{L}$ of cDNA, 5 $\mu \mathrm{L}$ of Fast SYBR Green PCR Master Mix (Applied Biosystems Inc., Foster City, CA), and $2 \mu \mathrm{L}$ of primers (Applied Biosystems Inc.) was used for amplification and quantification. The primer concentrations are presented in Table 2. The PCR conditions consisted of denaturation at $95^{\circ} \mathrm{C}$ for $20 \mathrm{~s}$ and then 40 cycles of amplification at $95^{\circ} \mathrm{C}$ for $3 \mathrm{~s}$ and $60^{\circ} \mathrm{C}$ for $30 \mathrm{~s}$. The samples were quantified with standard curve experiments run on a StepOnePlus real-time PCR system (Applied Biosystems Inc.) using a standard curve derived from a serial dilution of the pool. The genes $A C T B$ (actin, $\beta$ ), GAPDH (glyceraldehyde-3-phosphate dehydrogenase), PPIA (peptidylprolyl isomerase A), and YWHAZ (tyrosine 3-monooxygenase/tryptophan 5 -monooxygenase activation protein, zeta) were tested 
Table 2. Primers used during real-time PCR

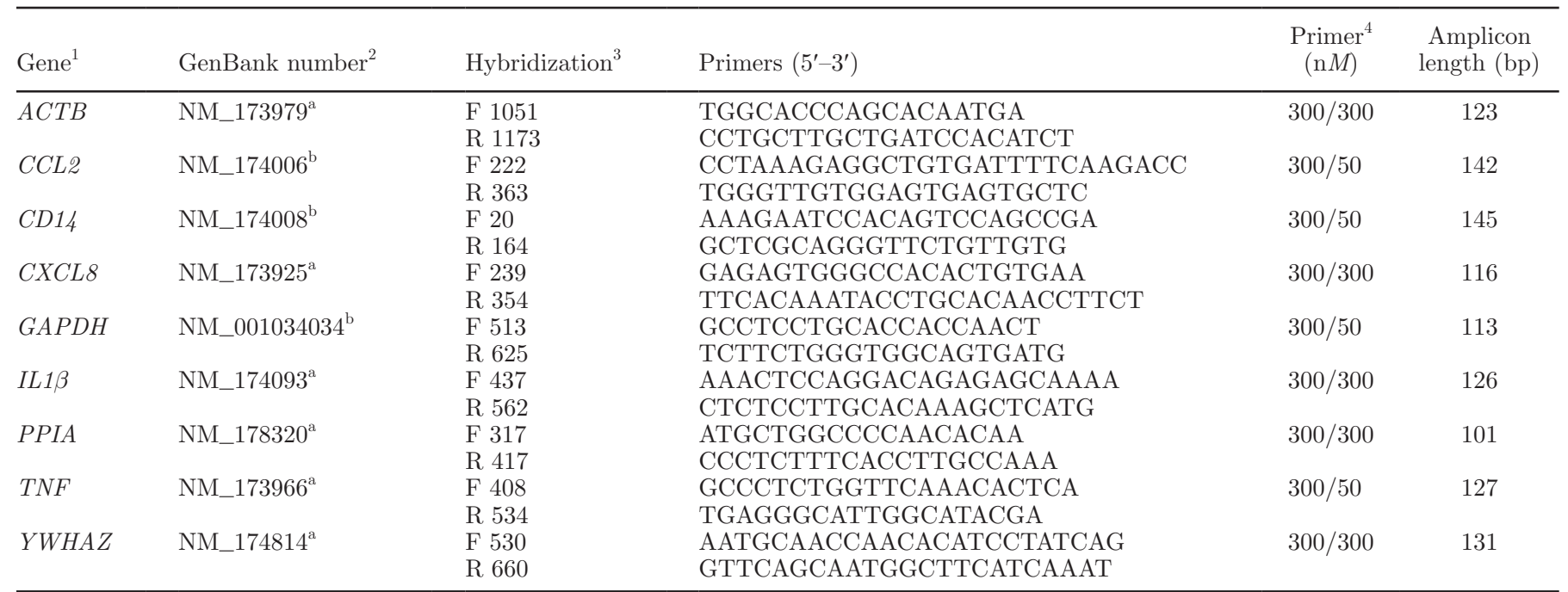

${ }^{1} A C T B=$ actin, $\beta ; C C L 2=$ chemokine $(\mathrm{C}-\mathrm{C}$ motif $)$ ligand $2 ; C D 14=\mathrm{CD} 14$ molecule; $C X C L 8=$ chemokine $(\mathrm{C}-\mathrm{X}-\mathrm{C}$ motif $)$ ligand $8 ; I L 1 \beta=$ Bos taurus IL1 $\beta$; PPIA = peptidylprolyl isomerase A; TNF = tumor necrosis factor; YWHAZ = tyrosine 3-monooxygenase/tryptophan 5-monooxygenase activation protein, zeta.

${ }^{2}$ Primers were either (a) taken from Dudemaine et al. (2014) or (b) designed using the Ensembl gene browser (Yates et al., 2016) following the primer design of Brosseau et al. (2010; http://test.lgfus.ca/cgi-bin/designs/index.pl).

${ }^{3} \mathrm{~F}=$ forward, $\mathrm{R}=$ reverse.

${ }^{4}$ Primer concentrations ranging from 50 to $900 \mathrm{n} M$ were tested during optimization reactions.

as potential housekeeping genes for the normalization of gene expression using NormFinder software (Andersen et al., 2004). For experiment 1, expression of the PPIA and $Y W H A Z$ genes showed less variability between treatments, and those genes were therefore selected as the housekeeping genes. For experiment 2, GAPDH and $Y W H A Z$ were selected as the housekeeping genes. The normalized values were obtained from the ratio of the expression of the gene of interest to the geometric mean of the respective housekeeping genes.

\section{Statistical Analysis}

Data were analyzed by ANOVA using the MIXED procedure of SAS software (version 9.0, SAS Institute Inc., Cary, NC). For experiment 1, time was used as a repeated effect, and treatment(cow) was used as the subject. Orthogonal contrasts were performed to compare the effect of each treatment to that of the control. Other treatment comparisons were performed using the Tukey-Kramer adjustment. For experiment 2 , data were analyzed as a factorial design with chitosan and teat sealant as main factors. Time was used as a repeated effect, and sealant $\times$ chitosan(cow) was used as the subject. When variances were not homogeneous, data were $\log _{10}$-transformed before analyses. Differences were considered statistically significant when $P \leq 0.05$ and considered a trend when $P<0.1$.

\section{RESULTS}

\section{Experiment 1}

The udder quarter inflammation scores for the periods from 0 to $24 \mathrm{~h}, 25$ to $48 \mathrm{~h}$, and 49 to $170 \mathrm{~h}$ after the infusions are presented in Table 3 . In the period from 0 to $24 \mathrm{~h}$, the average inflammation scores were slightly greater in the quarters treated with LV2.5 $(P<$ $0.01)$ and LV5 $(P<0.01)$ than in the control quarters. Conversely, the quarters treated with HV5 were not significantly $(P>0.1)$ different from the control quarters in terms of inflammation scores. No differences in inflammation scores were observed after $24 \mathrm{~h}(P>0.1)$.

The SCC, LDH activity, and BSA and lactoferrin concentrations measured in milk and mammary secretions are presented in Figure 1. No differences were observed between the quarters for all these parameters during the pretreatment period (on $\mathrm{d}-4$ and $-1 ; P>$ 0.1 ). All measured markers increased from the day of drying-off $(\mathrm{d}-1)$ to $\mathrm{d} 10(P<0.001)$, regardless of the treatment. However, all parameters showed a treatment $\times$ time interaction $(P<0.001)$. The concentration of BSA was greater $(P<0.001)$ on $\mathrm{d} 1$ to 5 in the quarters treated with chitosan than in the control quarters. Similarly, lactoferrin concentration in all the chitosantreated quarters was greater on d $3(P<0.001)$ and $5(P<0.01)$ in comparison with the control quarters. On d 1 to $7, \mathrm{LDH}$ activity was greater in the quarters 
Table 3. Average inflammation scores for 3 periods $(0-24 \mathrm{~h}, 25-48 \mathrm{~h}$, and $49-170 \mathrm{~h})$ after the infusion of dairy cow udder quarters at drying-off with $2.5 \mathrm{~mL}$ of $5 \%$ low-viscosity chitosan solution (LV2.5; $\mathrm{n}=7$ ), $5 \mathrm{~mL}$ of $5 \%$ low-viscosity chitosan solution (LV5; $\mathrm{n}=7$ ), $5 \mathrm{~mL}$ of $5 \%$ highviscosity chitosan solution (HV5; $\mathrm{n}=7$ ), or water (control, CTRL; $\mathrm{n}=7)^{1}$

\begin{tabular}{|c|c|c|c|c|c|c|c|c|}
\hline Period & \multicolumn{4}{|c|}{ Treatment } & SEM & \multicolumn{3}{|c|}{$P$-value } \\
\hline $0-24 \mathrm{~h}$ & 1.39 & 1.39 & 1.13 & 1.02 & 0.07 & $<0.01$ & $<0.01$ & 0.31 \\
\hline $49-170 \mathrm{~h}$ & 1.11 & 1.11 & 1.05 & 1.16 & 0.06 & 0.52 & 0.51 & 0.21 \\
\hline
\end{tabular}

${ }^{1}$ Data are presented as LSM.

treated with chitosan $(P<0.01)$ than in the control quarters. Somatic cell count was greater $(P<0.001)$ on $\mathrm{d} 1$ to 5 in all the chitosan-treated quarters than in the control quarters. Except on d 1, when the SCC in the LV-treated quarters was greater in comparison with that of the HV5-treated quarters $(P<0.01)$, no differences were present between the chitosan-treated quarters for all parameters.

The proportions of monocytes, granulocytes, and lymphocytes plus other cell types in milk are presented in Table 4. The proportion of monocytes decreased $(P<0.001)$ and that of granulocytes increased $(P<$ 0.001 ) after drying-off. Treatments had no effect on the proportion of these cell populations.

The expression of key immune regulators-CXCL8 [chemokine (C-X-C motif) ligand 8], CCL2 [chemokine (C-C motif) ligand 2], TNF (tumor necrosis factor), CD14 (CD14 molecule), and IL1 $\beta$ (Bos taurus IL1 $\beta$ )by somatic cells was determined on $\mathrm{d} 1,3$, and 5 after the treatments, and the results are presented in Table
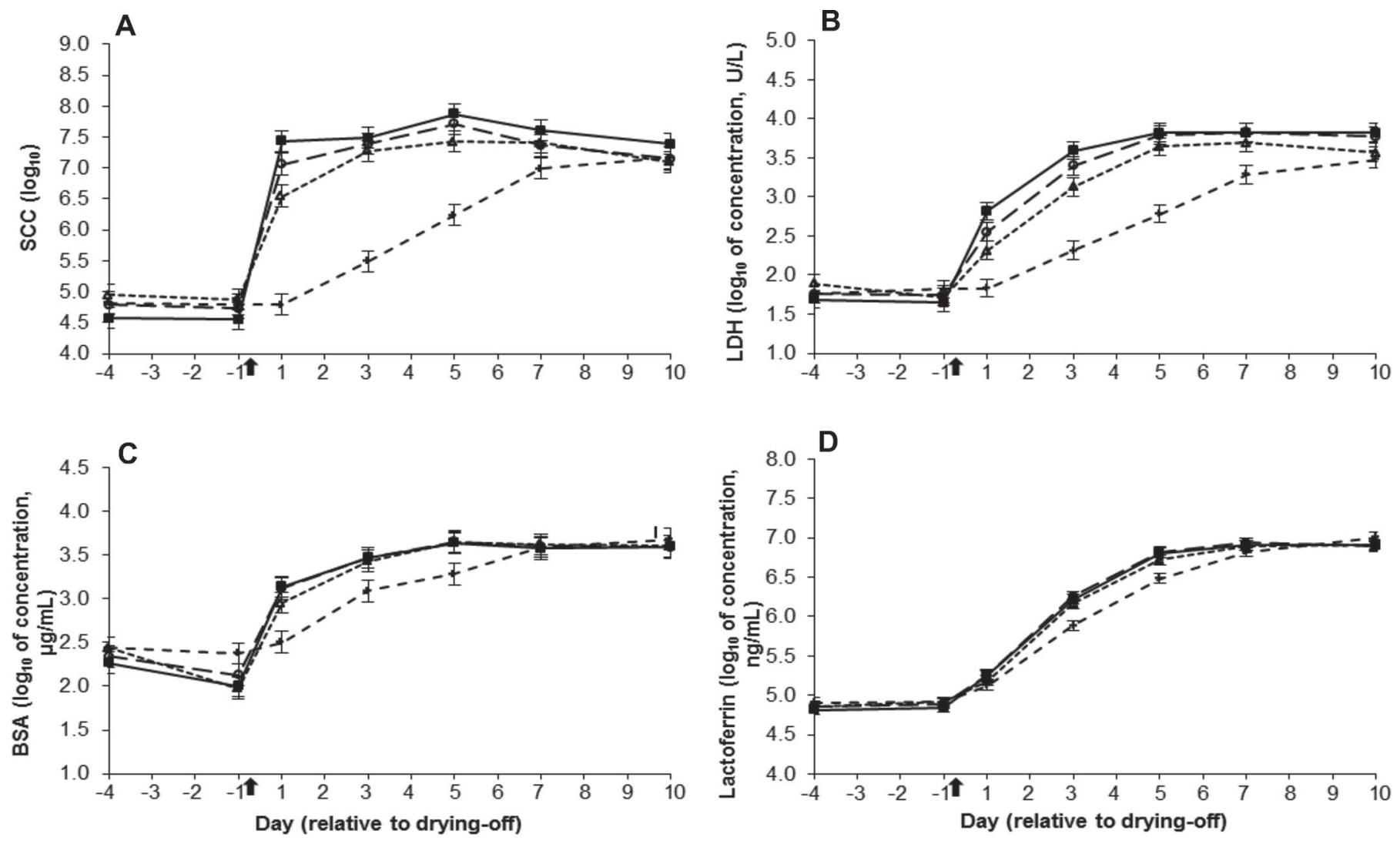

Figure 1. Somatic cell count (A), lactate dehydrogenase (LDH) activity (B), BSA concentration (C), and lactoferrin concentration (D) in milk and mammary secretions from dairy cow udder quarters infused at drying-off with $5 \mathrm{~mL}$ of $5 \%$ low-viscosity chitosan solution $(\boldsymbol{\square}$, solid line; $\mathrm{n}=7), 2.5 \mathrm{~mL}$ of $5 \%$ low-viscosity chitosan $(\mathrm{O}$, long-dashed line; $\mathrm{n}=7), 5 \mathrm{~mL}$ of $5 \%$ high-viscosity chitosan solution $(\Delta$, short-dashed line; $\mathrm{n}$ $=7$ ), or $5 \mathrm{~mL}$ of water (control; + , medium-dashed line; $\mathrm{n}=7$ ). Treatment time is indicated by an arrow. Data are presented as LSM \pm SEM of $\log _{10}$-transformed values. 
Table 4. Percentages of somatic cell types (monocytes, granulocytes, lymphocytes + others) before $(\mathrm{d}-1)$ and after $(\mathrm{d} 1)$ the infusion of dairy cow udder quarters at drying-off with $2.5 \mathrm{~mL}$ of $5 \%$ low-viscosity chitosan solution (LV2.5; n $=6$ ), $5 \mathrm{~mL}$ of $5 \%$ low-viscosity chitosan solution $(\mathrm{LV} 5 ; \mathrm{n}=6), 5 \mathrm{~mL}$ of $5 \%$ high-viscosity chitosan solution $(\mathrm{HV} 5 ; \mathrm{n}=6)$, or water $(\text { control, CTRL; } \mathrm{n}=6)^{1}$

\begin{tabular}{|c|c|c|c|c|c|c|c|c|c|c|c|c|}
\hline Cell type & \multicolumn{4}{|c|}{$\mathrm{d}-1$} & \multicolumn{4}{|c|}{ d 1} & SEM & \multicolumn{3}{|c|}{$P$-value } \\
\hline Monocytes & 32.4 & 30.6 & 26.9 & 33.8 & 25.8 & 23.6 & 18.9 & 16.4 & 3.7 & 0.46 & $<0.001$ & 0.34 \\
\hline Lymphocytes + others & 23.3 & 23.9 & 20.3 & 22.4 & 24.1 & 14.0 & 20.5 & 16.6 & 3.3 & 0.53 & 0.12 & 0.31 \\
\hline
\end{tabular}

${ }^{1}$ Data are presented as LSM. TRT $=$ treatment.

5. We observed a treatment $\times$ day interaction $(P<$ $0.01)$ for the expression of all genes. Gene expression was greater on $\mathrm{d} 1$ than on $\mathrm{d} 3$ for $C X C L 8(P<0.001)$, TNF $(P=0.09)$, and $I L 1 \beta(P=0.04)$. In comparison with $\mathrm{d} 5$, gene expression on $\mathrm{d} 1$ was greater $(P<0.01)$ for CXCL8,CCL2, TNF, CD14, and IL1 $\beta$. On d 1, the quarters treated with chitosan had greater expression of $C X C L 8(P<0.001)$, CCL2 $(P<0.01)$, TNF $(P<$ $0.001), C D 14(P<0.001)$, and $I L 1 \beta(P<0.01)$ than the control quarters. On $\mathrm{d} 3$, the quarters treated with chitosan had greater expression of TNF $(P<0.01)$ than the control quarters. The quarters treated with chitosan had greater expression of $C X C L 8(P=0.02)$, and tend to have greater expression of TNF $(P=0.09)$, and $C D 14(P=0.08)$ on d 5 in comparison with the control quarters. The quarters treated with HV5 had greater expression of CXCL8 $(P<0.01), C C L 2(P<0.01)$, TNF $(P<0.01), C D 14(P=0.09)$, and $\operatorname{IL1} \beta(P=$
$0.06)$ on $\mathrm{d} 1$, of $\operatorname{TNF}(P<0.01)$ and $C D 14(P<0.001)$ on $\mathrm{d} 3$, and $\operatorname{IL} 1 \beta(P<0.01)$ on $\mathrm{d} 5$ in comparison with the low viscosity-treated quarters. The quarters treated with LV5 had greater expression of IL1 $\beta(P<0.01)$ on d 5 than those treated with LV2.5.

\section{Experiment 2}

The udder quarter inflammation scores were increased $(P<0.01)$ by chitosan during the first period, from 0 to $24 \mathrm{~h}$ after the treatments (Table 6 ). Sealant did not have an effect or interact $(P>0.1)$ with chitosan on inflammation scores. Sealant and chitosan did not affect $(P<0.1)$ inflammation scores after the first day.

The immune and involution markers measured in milk and mammary secretions are presented in Figure 2. During the pretreatment period (on $\mathrm{d}-4$ and -1 ), no differences were observed between the udder

Table 5. Normalized expression in milk of the somatic cell genes CXCL8 [chemokine (C-X-C motif) ligand 8], IL1 $\beta$ (Bos taurus IL1 $\beta$ ), TNF (tumor necrosis factor), CCL2 [chemokine (C-C motif) ligand 2], and CD14 (CD14 molecule) on d 1, 3, and 5 after the infusion of dairy cow udder quarters at drying-off with $2.5 \mathrm{~mL}$ of $5 \%$ low-viscosity chitosan solution (LV2.5; n = 7), $5 \mathrm{~mL}$ of $5 \%$ low-viscosity chitosan solution (LV5; $\mathrm{n}=7$ ), $5 \mathrm{~mL}$ of $5 \%$ high-viscosity chitosan solution (HV5; $\mathrm{n}=7$ ), or water (control, CTRL; $\mathrm{n}=7)^{1}$

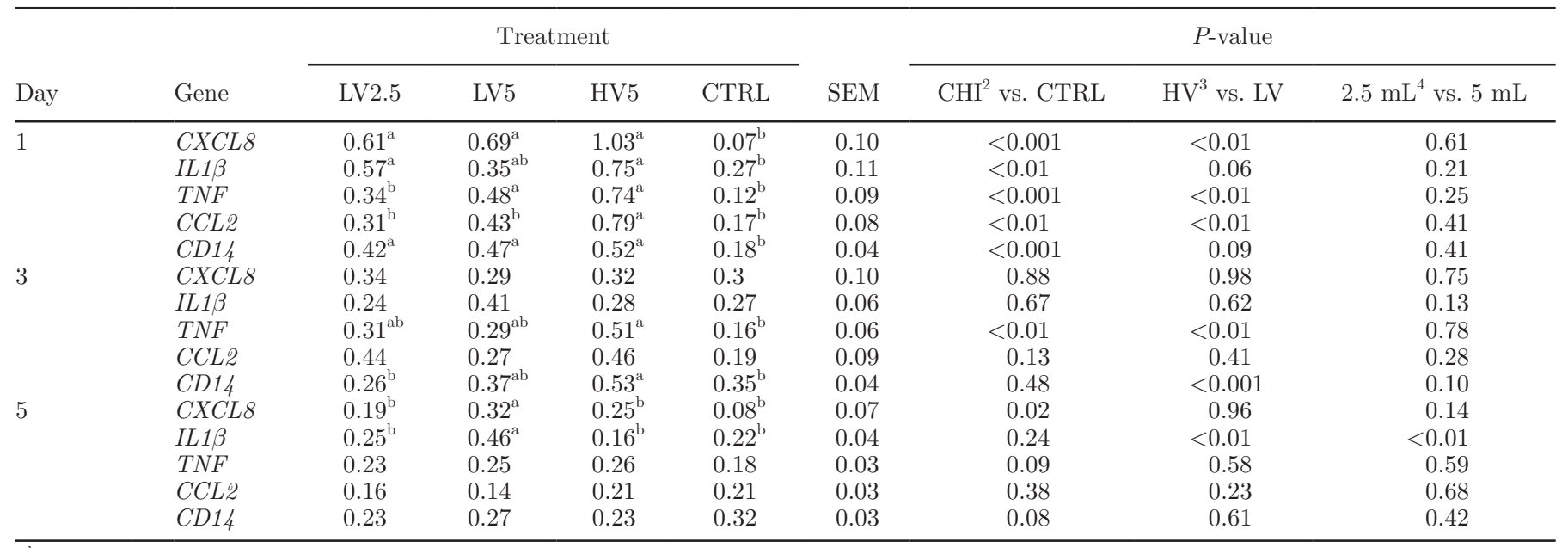

\footnotetext{
${ }^{1}$ Data are presented as LSM of $\log _{10}$-transformed values.

${ }^{2} \mathrm{LV} 2.5+\mathrm{LV} 5+\mathrm{HV} 5$ versus CTRL.

${ }^{3} \mathrm{HV} 5$ versus LV2.5+LV5.

${ }^{4} \mathrm{LV} 2.5$ versus LV5.
}

$\overline{\mathrm{a}, \mathrm{b}}$ Different letters indicate significant differences $(P<0.05)$ among treatments. 

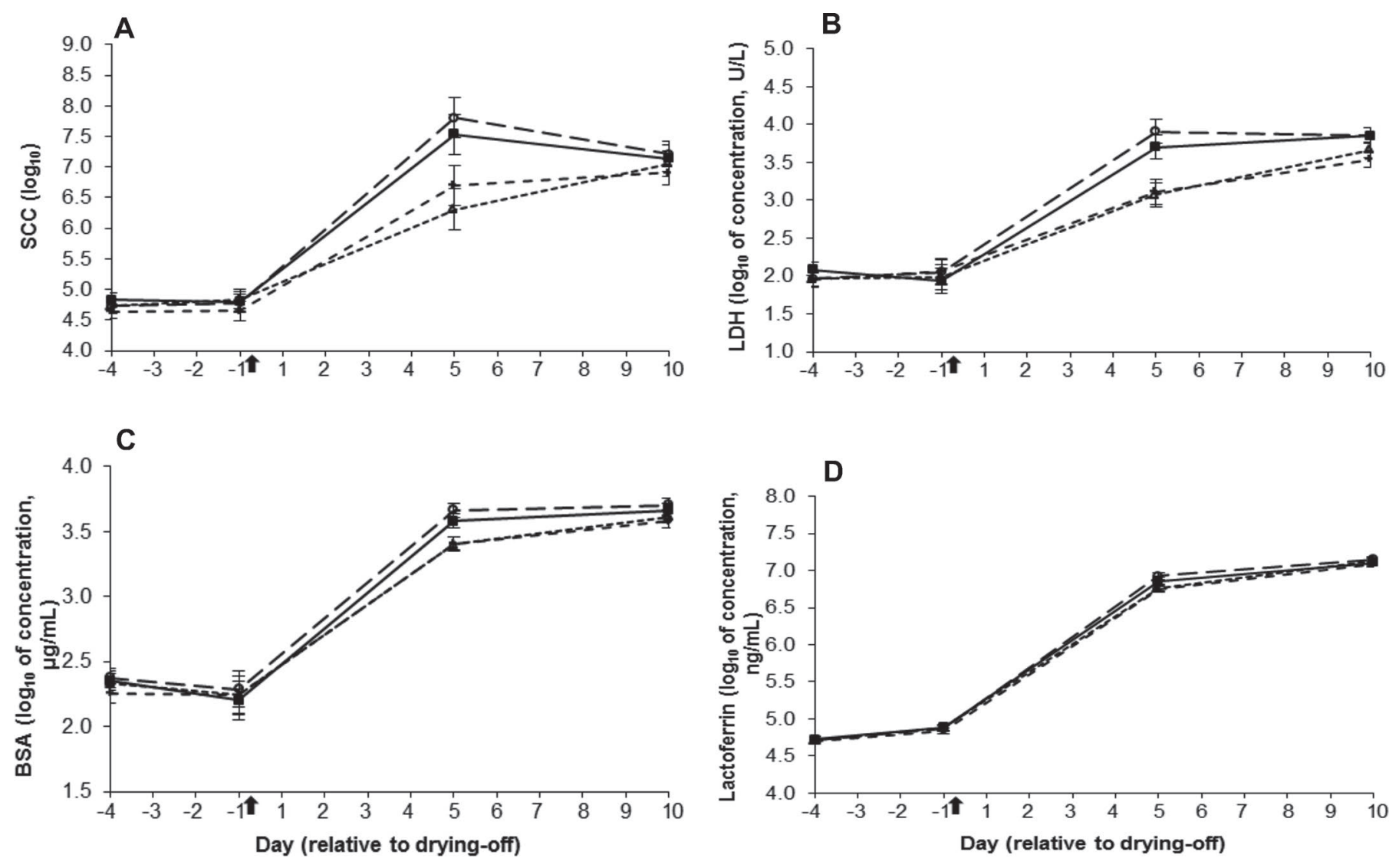

Figure 2. Somatic cell count (A), lactate dehydrogenase (LDH) activity (B), BSA concentration (C), and lactoferrin concentration (D) in milk and mammary secretions from dairy cow udder quarters infused at drying-off with $5 \mathrm{~mL}$ of $2 \%$ low-viscosity chitosan solution ( $\mathbf{\square}$, solid line; $\mathrm{n}=8), 4 \mathrm{~g}$ of teat sealant solution followed by $5 \mathrm{~mL}$ of $2 \%$ low-viscosity chitosan solution ( $\bigcirc$, long-dashed line; $\mathrm{n}=8), 4 \mathrm{~g}$ of teat sealant solution $(\Delta$, short-dashed line; $\mathrm{n}=8)$, or $5 \mathrm{~mL}$ of water (control; + , medium-dashed line; $\mathrm{n}=8)$. Treatment time is indicated by an arrow. Data are presented as LSM \pm SEM of $\log _{10}$-transformed values.

quarters for all these parameters. Additionally, in every quarter, all measured markers increased from the day of drying-off $(\mathrm{d}-1)$ to $\mathrm{d} 10(P<0.001)$. Nevertheless, we observed a chitosan $\times$ time interaction for BSA concentration $(P<0.01)$, lactoferrin concentration $(P=$ $0.06)$, LDH activity $(P<0.001)$, and SCC $(P<0.001)$. On d 5, milk from the chitosan-treated quarters had greater BSA $(P<0.01)$, lactoferrin $(P=0.001), \mathrm{LDH}$ $(P<0.0001)$, and SCC $(P<0.001)$ values than the quarters without chitosan. The infusion of sealant did not have an effect $(P>0.1)$ or interact with chitosan on any of these markers.

The proportions of monocytes, granulocytes, and lymphocytes plus other cell types in milk are presented in Table 7. After drying-off, the proportions of monocytes $(P<0.001)$ and lymphocytes plus other cell types $(P<0.01)$ decreased. Conversely, the proportion of granulocytes increased $(P<0.001)$ after drying-off.

Table 6. Average inflammation scores for 3 periods $(0-24 \mathrm{~h}, 25-48 \mathrm{~h}$, and $49-170 \mathrm{~h})$ after the infusion of dairy cow udder quarters at drying-off with $5 \mathrm{~mL}$ of $2 \%$ low-viscosity chitosan solution (CHI; $\mathrm{n}=8), 4 \mathrm{~g}$ of teat sealant solution followed by $5 \mathrm{~mL}$ of $2 \%$ low-viscosity chitosan solution (CHI + SEAL; $\mathrm{n}=8$ ), $4 \mathrm{~g}$ of teat sealant solution (SEAL; $\mathrm{n}=8$ ), or water (control, CTRL; $\mathrm{n}=8)^{1}$

\begin{tabular}{|c|c|c|c|c|c|c|c|}
\hline \multirow[b]{2}{*}{ Period } & \multicolumn{4}{|c|}{ Treatment } & \multicolumn{3}{|c|}{$P$-value } \\
\hline & $\mathrm{CHI}$ & $\mathrm{CHI}+\mathrm{SEAL}$ & SEAL & CTRL & SEAL & CHI & $\mathrm{SEAL} \times \mathrm{CHI}$ \\
\hline $0-24 \mathrm{~h}$ & $1.76 \pm 0.14$ & $1.55 \pm 0.14$ & $1.19 \pm 0.18$ & $1.25 \pm 0.18$ & 0.47 & $<0.01$ & 0.67 \\
\hline $25-48 \mathrm{~h}$ & $1.30 \pm 0.10$ & $1.30 \pm 0.10$ & $1.45 \pm 0.13$ & $1.45 \pm 0.13$ & 1.00 & 0.14 & 1.00 \\
\hline $49-170 \mathrm{~h}$ & $1.06 \pm 0.06$ & $1.11 \pm 0.06$ & $1.18 \pm 0.07$ & $1.08 \pm 0.07$ & 0.30 & 0.40 & 0.73 \\
\hline
\end{tabular}

${ }^{1}$ Data are presented as LSM \pm SE of the LSM. 
Chitosan and teat sealant had no effect on the proportions of these cell populations.

The expression of key immune regulators (CXCL8, CCL2, TNF, CD14, and IL1ß) by somatic cells was determined on d 5 after the treatments, and the results are presented in Table 8. Chitosan increased expression of the somatic cell genes $C X C L 8(P<0.001), C C L 2(P$ $<0.001)$, and $I L 1 \beta(P<0.01)$. However, gene expression of TNF and CD14 was not affected by chitosan. The infusion of sealant did not affect $(P>0.1)$ or interact with chitosan on any of these genes.

\section{DISCUSSION}

In both of our experiments, the chitosan hydrogel infusions significantly hastened the increase in both BSA and lactoferrin concentrations in mammary secretions after drying-off. Our results demonstrate that the intramammary infusion of chitosan hydrogel at dryingoff disrupted tight junction integrity and changed the cells' secretory state, therefore hastening the involution process. These results are consistent with a previous report suggesting that chitosan has the ability to alter tight junctions (Yeh et al., 2011).

Lactoferrin also acts as an immune factor that protects the mammary gland. Lactoferrin disrupts the outer membrane of gram-negative bacteria but also binds iron, making it unavailable for iron-dependent bacteria (Ellison et al., 1988). Given that the concentration of lactoferrin increased faster in the mammary secretions of the chitosan-treated cows, mammary gland defense may be improved by the infusion of chitosan hydrogel.

In this study, we also assessed mammary epithelium integrity by measuring the activity in mammary secretions of $\mathrm{LDH}$ released by damaged cells. In both experiments, we observed a transient increase in LDH activity as involution progressed. Moreover, all chitosan hydrogel infusions significantly hastened the increase in LDH activity after drying-off. In experiment 1, the 3 chitosan formulations resulted in similar effects on LDH activity. The increase in milk LDH activity suggests a cytotoxic effect of chitosan on mammary epithelium. Symons and Wright (1974) reported that elevated milk LDH above serum levels found in mastitis milk was released from damaged mammary epithelium caused by endotoxin. However, according to Kato et al. (1989), leukocytes also participate in the increase in milk LDH activity during mastitis. This effect can be explain by the high LDH activity, $1,000 \mathrm{U} / \mathrm{mg}$ of protein, of leukocytes.

The number of somatic cells increases in mammary secretions during the early involution period (Jensen and Eberhart, 1981). Evidence indicates that immune cells play an important role in mammary gland defense,

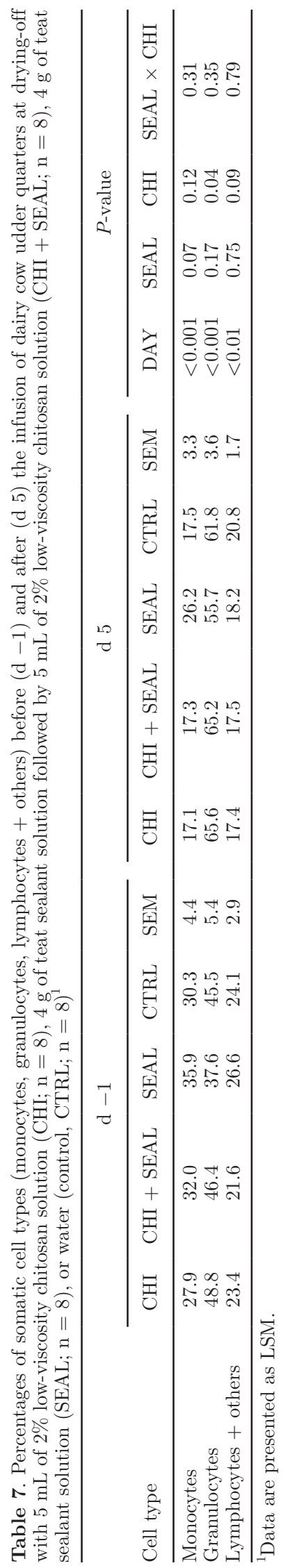


Table 8. Normalized milk somatic cell gene expression of CXCL8 [chemokine (C-X-C motif) ligand 8], IL1 $\beta$ (Bos taurus IL1 $\beta$ ), TNF (tumor necrosis factor), CCL2 [chemokine (C-C motif) ligand 2], and CD14 (CD14 molecule) on d 5 after the infusion of dairy cow udder quarters at drying-off with $5 \mathrm{~mL}$ of $2 \%$ low-viscosity chitosan solution (CHI; $\mathrm{n}=8), 4 \mathrm{~g}$ of teat sealant solution followed by $5 \mathrm{~mL}$ of $2 \%$ low-viscosity chitosan solution $(\mathrm{CHI}+\mathrm{SEAL} ; \mathrm{n}=8), 4 \mathrm{~g}$ of teat sealant solution (SEAL; $\mathrm{n}=8)$, or water (control, $\mathrm{CTRL} ; \mathrm{n}=8)^{1}$

\begin{tabular}{|c|c|c|c|c|c|c|c|c|c|}
\hline \multirow[b]{2}{*}{ Item } & \multirow[b]{2}{*}{ Gene } & \multicolumn{4}{|c|}{ Treatment } & \multirow[b]{2}{*}{ SEM } & \multicolumn{3}{|c|}{$P$-value } \\
\hline & & $\mathrm{CHI}$ & $\mathrm{CHI}+\mathrm{SEAL}$ & SEAL & CTRL & & SEAL & CHI & $\mathrm{SEAL} \times \mathrm{CHI}$ \\
\hline & $T N F$ & 0.22 & 0.21 & 0.21 & 0.13 & 0.04 & 0.28 & 0.17 & 0.21 \\
\hline & CCL2 & $0.20^{\mathrm{a}}$ & $0.26^{\mathrm{a}}$ & $0.10^{\mathrm{b}}$ & $0.09^{\mathrm{b}}$ & 0.03 & 0.23 & $<0.001$ & 0.32 \\
\hline & $C D 14$ & 0.24 & 0.25 & 0.28 & 0.28 & 0.03 & 0.73 & 0.20 & 0.85 \\
\hline
\end{tabular}

${ }^{\mathrm{a}, \mathrm{b}}$ Different letters indicate significant differences $(P<0.05)$ among treatments.

${ }^{1}$ Data are presented as LSM of $\log _{10}$-transformed values.

particularly at the Furstenberg's rosette, which is a structure strategically located at the internal end of the streak canal. At this location, immune cells leave the teat wall and enter the teat cistern to intercept bacteria before they reach the mammary gland (Nickerson and Pankey, 1983). The intramammary administration of proinflammatory agents increases the number of somatic cells in the gland (Oliver and Sordillo, 1989; Wedlock et al., 2004). In both of our experiments, SCC in mammary secretions increased faster in all the chitosan-treated quarters than in the control quarters. In experiment 1, we observed a significant increase in $\mathrm{SCC}$ in the chitosan-treated quarters only $24 \mathrm{~h}$ after the treatment was administered. Moreover, in both experiments, the elevated SCC in the mammary secretions from the chitosan-treated quarters were maintained throughout the experimental period. These results are consistent with the literature reports of chitosan's immunostimulating properties (Otterlei et al., 1994; Wen et al., 2011).

The SCC in mammary secretions increases during an immune response as well as during involution. In both cases, the proportions of somatic cell types also change (Hurley, 1989; Sordillo and Streicher, 2002). In both of our experiments, the proportion of polymorphonuclear neutrophils increased after drying-off. During the first 3 to $7 \mathrm{~d}$ of drying-off, polymorphonuclear neutrophils are the main types of leukocytes entering the mammary gland (Hurley, 1989). Similarly, during an infection, the proportion of polymorphonuclear neutrophils increases drastically and can reach $90 \%$ of leukocytes (Sordillo and Streicher, 2002). However, no treatment effect was found on somatic cell types for both experiments. These results confirm that chitosan has the ability to activate immune pathways that accelerate the infiltration of multiple types of inflammatory cells simultaneously (Ueno et al., 1999).

To provide optimal protection against pathogens, the mammary gland immune system needs to be activated
(Sordillo and Streicher, 2002). Once that activation has occurred, the expression of immunoregulatory genes by mammary immune and epithelial cells increases. As a result, those cells produce and release proinflammatory cytokines that bind to macrophage and neutrophil receptors and increase their bactericidal capacity (Oviedo-Boyso et al., 2007). In both of our experiments, the chitosan hydrogel infusions increased the expression of immunoregulatory genes by somatic cells. In experiment 1, gene expression was measured on the first samples harvested $24 \mathrm{~h}$ after the treatments were administered. At this time, we observed elevated expression of the genes CXCL8, CCL2, TNF, CD14, and $I L 1 \beta$ caused by the chitosan hydrogels. On the following days (d 3 and 5 ), the treatment effect on immune gene expression was decreased. In experiment 2 , gene expression was measured on samples harvested 5 $\mathrm{d}$ after the treatments were administered. At this time, expression of the genes CXCL8,CCL2, and $I L 1 \beta$ was still greater in the chitosan-treated udder quarters.

The processes by which chitosan triggers host immune responses are still only partly understood. One possible explanation is the recognition of chitin and chitosan polymers as foreign molecules by the mammalian innate immune system (Bueter et al., 2013). Otterlei et al. (1994) observed TNF- $\alpha$ production upon activation of monocytes by chitosan. Because chitosan structure is similar to that of LPS, those authors suggested that chitosan is involved in CD14 activation. Bueter et al. (2011) suggested that the phagocytosis of enzyme-degraded chitosan particles activates the NLRP3 inflammasome, which in turn induces $I L 1 \beta$ production. Overall, chitosan's immunomodulatory properties activate immune cells and accelerate proinflammatory cytokine production and, therefore, should increase protection against infections (Şenel and McClure, 2004).

Ideally, a BRM should induce the moderate recruitment of immune cells into the teat without causing acute inflammation symptoms. In experiment 1, 
quarters treated with low-viscosity chitosan showed transient signs of inflammation during the first $24 \mathrm{~h}$ following the administration of the treatments. Therefore, for experiment 2 we used the same chitosan but at a lower concentration. Similarly, during that experiment, the inflammation scores during the period from 0 to $24 \mathrm{~h}$ of the quarters treated with chitosan were greater than those scores of the quarters without chitosan. The injected chitosan dosage that was used in our study resulted in transient signs of inflammation similar to those observed during the infusion of other BRM (Oliver and Smith, 1982; Dallard et al., 2010). Nevertheless, in all cases in our study, inflammation symptoms were mild and transient.

Teat sealing is a substitute for prophylactic antibiotic dry-cow therapy. Long-lasting, biocompatible, bismuthbased preparations can remain stable in the teat canal throughout the dry period and act as a physical barrier against invading pathogens. Krömker et al. (2014) showed a decrease in infection rate to a third of that of the control quarters when quarters were treated with sealant only during the dry period. Therefore, the use of teat sealant is beneficial but not fully effective. In experiment 2 , the sealant did not affect involution and immune response markers but also did not alter the effect of the chitosan hydrogel when both substances were injected into the same quarter. Thus, both approaches are fully compatible and could be used in combination.

The results of the present study suggest that a chitosan hydrogel infusion activates innate immune response and hastens the involution process of the mammary gland. Ollier et al. $(2014,2015)$ demonstrated that prolactin-release inhibition hastens mammary involution, resulting in reduced susceptibility to IMI. Although this effect needs to be evaluated, the administration of chitosan hydrogel at drying-off could also reduce the incidence of new cases of IMI during the dry period. Ultimately, this approach could be used as an alternative to dry-cow antibiotic therapy for uninfected cows.

\section{ACKNOWLEDGMENTS}

The authors thank the following people (all from Agriculture and Agri-Food Canada, Sherbrooke, QC, Canada): Séverine Ollier, Véronique Roy, Catherine Thibault, Izabella Thompson, Jinjin Tong, Noémie Vanacker, Frédéric Beaudoin, Steve Méthot, and Shirley Caron for providing technical assistance, and the dairy barn staff for taking care of the cows. The authors are grateful to Mary Varcoe, from the Translation Bureau, Public Works and Government Services Canada, for her careful editing of this manuscript. This research was financially supported by the Canadian Bovine Mastitis Research Network, Dairy Farmers of Canada, and Agriculture and Agri-Food Canada, as well as by a scholarship from Canadian Dairy Commission in collaboration with Novalait Inc. (Québec, QC, Canada).

\section{REFERENCES}

Andersen, C. L., J. L. Jensen, and T. F. Ørntoft. 2004. Normalization of real-time quantitative reverse transcription-PCR data: A model-based variance estimation approach to identify genes suited for normalization, applied to bladder and colon cancer data sets. Cancer Res. 64:5245-5250. https://doi.org/10.1158/0008-5472. CAN-04-0496.

Andersen, J. B., T. G. Madsen, T. Larsen, K. L. Ingvartsen, and M. O. Nielsen. 2005. The effects of dry period versus continuous lactation on metabolic status and performance in periparturient cows. J. Dairy Sci. 88:3530-3541. https://doi.org/10.3168/jds.S00220302(05)73038-1.

Berry, E. A., and J. E. Hillerton. 2002. The effect of selective dry cow treatment on new intramammary infections. J. Dairy Sci. 85:112121. https://doi.org/10.3168/jds.S0022-0302(02)74059-9.

Bouchard, L., S. Blais, C. Desrosiers, X. Zhao, and P. Lacasse. 1999. Nitric oxide production during endotoxin-induced mastitis in the cow. J. Dairy Sci. 82:2574-2581. 10.3168/jds.S0022-0302(99)755128 .

Brosseau, J.-P., J.-F. Lucier, E. Lapointe, M. Durand, D. Gendron, J. Gervais-Bird, K. Tremblay, J.-P. Perreault, and S. A. Elela. 2010. High-throughput quantification of splicing isoforms. RNA 16:442-449. https://doi.org/10.1261/rna.1877010.

Bueter, C. L., C. K. Lee, V. A. K. Rathinam, G. J. Healy, C. H. Taron, C. A. Specht, and S. M. Levitz. 2011. Chitosan but not chitin activates the inflammasome by a mechanism dependent upon phagocytosis. J. Biol. Chem. 286:35447-35455. https://doi.org/10.1074/ jbc.M111.274936.

Bueter, C. L., C. A. Specht, and S. M. Levitz. 2013. Innate sensing of chitin and chitosan. PLoS Pathog. 9:e1003080 https://doi. org/10.1371/journal.ppat.1003080.

Canadian Council on Animal Care. 1993. Guide to the care and use of experimental animals. Vol. 1. 2nd ed. E. D. Olfert, B. M. Cross, and A. A. McWilliam, ed. CCAC, Ottawa, ON, Canada.

Capuco, A. V., and R. M. Akers. 1999. Mammary involution in dairy animals. J. Mammary Gland Biol. Neoplasia 4:137-144.

Chenite, A., C. Chaput, D. Wang, C. Combes, M. D. Buschmann, C. D. Hoemann, J. C. Leroux, B. L. Atkinson, F. Binette, and A. Selmani. 2000. Novel injectable neutral solutions of chitosan form biodegradable gels in situ. Biomaterials 21:2155-2161.

Cousins, C. L., T. M. Higgs, E. R. Jackson, F. K. Neave, and F. H. Dodd. 1980. Susceptibility of the bovine udder to bacterial infection in the dry period. J. Dairy Res. 47:11-18.

Dallard, B. E., H. H. Ortega, I. A. Iguzquiza, N. R. Salvetti, O. A. Quaino, and L. F. Calvinho. 2010. The effect of a single intramammary infusion of a biological response modifier in cows at drying off. Vet. Res. Commun. 34:519-532. https://doi.org/10.1007/ s11259-010-9423-0.

Dingwell, R. T., K. E. Leslie, Y. H. Schukken, J. M. Sargeant, L. L. Timms, T. F. Duffield, G. P. Keefe, D. F. Kelton, K. D. Lissemore, and J. Conklin. 2004. Association of cow and quarter-level factors at drying-off with new intramammary infections during the dry period. Prev. Vet. Med. 63:75-89. https://doi.org/10.1016/j. prevetmed.2004.01.012.

Dudemaine, P. L., C. Thibault, K. Alain, and N. Bissonnette. 2014 Genetic variations in the SPP1 promoter affect gene expression and the level of osteopontin secretion into bovine milk. Anim. Genet. 45:629-640. https://doi.org/10.1111/age.12176.

Ellison, R. T. 3rd, T. J. Giehl, and F. M. LaForce. 1988. Damage of the outer membrane of enteric gram-negative bacteria by lactoferrin and transferrin. Infect. Immun. 56:2774-2781.

Hurley, W. L. 1989. Mammary gland function during involution. J. Dairy Sci. 72:1637-1646. https://doi.org/10.3168/jds.S0022 0302(89)79276-6. 
Jensen, D. L., and R. J. Eberhart. 1981. Total and differential cell counts in secretions of the nonlactating bovine mammary gland. Am. J. Vet. Res. 42:743-747.

Kato, K., K. Mori, and N. Katoh. 1989. Contribution of leucocytes to the origin of lactate dehydrogenase isozymes in milk of bovine mastitis. Nippon Juigaku Zasshi 51:530-539.

Krömker, V., N. T. Grabowski, and J. Friedrich. 2014. New infection rate of bovine mammary glands after application of an internal teat seal at dry-off. J. Dairy Res. 81:54-58. https://doi. org/10.1017/S0022029913000599

Leelahapongsathon, K., T. Piroon, W. Chaisri, and W. Suriyasathaporn. 2016. Factors in dry period associated with intramammary infection and subsequent clinical mastitis in early postpartum cows. Asian-australas. J. Anim. Sci. 29:580-585. https://doi. org/10.5713/ajas.15.0383.

National Mastitis Council. 1996. Current Concept of Bovine Mastitis. 4th ed. National Mastitis Council, Madison, WI.

Nguyen, D. A., and M. C. Neville. 1998. Tight junction regulation in the mammary gland. J. Mammary Gland Biol. Neoplasia 3:233246

Nickerson, S. C., and J. W. Pankey. 1983. Cytologic observations of the bovine teat end. Am. J. Vet. Res. 44:1433-1441.

Oliver, S. P., S. E. Murinda, and B. M. Jayarao. 2011. Impact of antibiotic use in adult dairy cows on antimicrobial resistance of veterinary and human pathogens: A comprehensive review. Foodborne Pathog. Dis. 8:337-355. https://doi.org/10.1089/fpd.2010.0730.

Oliver, S. P., and K. L. Smith. 1982. Bovine mammary involution following intramammary infusion on colchicine and endotoxin at drying off. J. Dairy Sci. 65:801-813.

Oliver, S. P., and L. M. Sordillo. 1989. Approaches to the manipulation of mammary involution. J. Dairy Sci. 72:1647-1664.

Ollier, S., X. Zhao, and P. Lacasse. 2014. Effects of feed restriction and prolactin-release inhibition at drying off on metabolism and mammary gland involution in cows. J. Dairy Sci. 97:4942-4954. https://doi.org/10.3168/jds.2014-7914.

Ollier, S., X. Zhao, and P. Lacasse. 2015. Effects of feed restriction and prolactin-release inhibition at drying-off on susceptibility to new intramammary infection in cows. J. Dairy Sci. 98:221-228. https://doi.org/10.3168/jds.2014-8426.

Otterlei, M., K. M. Vårum, L. Ryan, and T. Espevik. 1994. Characterization of binding and TNF- $\alpha$-inducing ability of chitosans on monocytes: The involvement of CD14. Vaccine 12:825-832.

Oviedo-Boyso, J., J. J. Valdez-Alarcón, M. Cajero-Juárez, A. OchoaZarzosa, J. E. López-Meza, A. Bravo-Patiño, and V. M. BaizabalAguirre. 2007. Innate immune response of bovine mammary gland to pathogenic bacteria responsible for mastitis. J. Infect. 54:399 409. https://doi.org/10.1016/j.jinf.2006.06.010.

Rambeaud, M., R. A. Almeida, G. M. Pighetti, and S. P. Oliver. 2003. Dynamics of leukocytes and cytokines during experimentally induced Streptococcus uberis mastitis. Vet. Immunol. Immunopathol. 96:193-205. https://doi.org/10.1016/j.vetimm.2003.08.008.

Rinaudo, M. 2006. Chitin and chitosan: Properties and applications. Prog. Polym. Sci. 31:603-632.

Senel, S., and S. J. McClure. 2004. Potential applications of chitosan in veterinary medicine. Adv. Drug Deliv. Rev. 56:1467-1480. https:// doi.org/10.1016/j.addr.2004.02.007.

Shamay, A., F. Shapiro, G. Leitner, and N. Silanikove. 2003. Infusions of casein hydrolyzates into the mammary gland disrupt tight junction integrity and induce involution in cows. J. Dairy Sci. $86: 1250-1258$.
Smith, K. L., D. A. Todhunter, and P. S. Schoenberger. 1985. Environmental pathogens and intramammary infection during the dry period. J. Dairy Sci. 68:402-417.

Sordillo, L. M., and S. C. Nickerson. 1988. Morphologic changes in the bovine mammary gland during involution and lactogenesis. Am. J. Vet. Res. 49:1112-1120.

Sordillo, L. M., S. C. Nickerson, R. M. Akers, and S. P. Oliver. 1987. Secretion composition during bovine mammary involution and the relationship with mastitis. Int. J. Biochem. 19:1165-1172. https:// doi.org/10.1016/0020-711X(87)90098-X.

Sordillo, L. M., and K. L. Streicher. 2002. Mammary gland immunity and mastitis susceptibility. J. Mammary Gland Biol. Neoplasia 7:135-146. https://doi.org/10.1023/a:1020347818725.

Swinkels, J. M., A. Hilkens, V. Zoche-Golob, V. Krömker, M. Buddiger, J. Jansen, and T. J. G. M. Lam. 2015. Social influences on the duration of antibiotic treatment of clinical mastitis in dairy cows. J. Dairy Sci. 98:2369-2380. https://doi.org/10.3168/jds.2014-8488.

Symons, D. B. A., and L. J. Wright. 1974. Changes in bovine mammary gland permeability after intramammary exotoxin infusion. J. Comp. Pathol. 84:9-17.

Tatarczuch, L., R. J. Bischof, C. J. Philip, and C.-S. Lee. 2002. Phagocytic capacity of leucocytes in sheep mammary secretions following weaning. J. Anat. 201:351-361. https://doi.org/10.1046/j.00218782.2002.00104.x.

Tzianabos, A. O. 2000. Polysaccharide immunomodulators as therapeutic agents: Structural aspects and biologic function. Clin. Microbiol. Rev. 13:523-533.

Ueno, H., H. Yamada, I. Tanaka, N. Kaba, M. Matsuura, M. Okumura, T. Kadosawa, and T. Fujinaga. 1999. Accelerating effects of chitosan for healing at early phase of experimental open wound in dogs. Biomaterials 20:1407-1414.

Wedlock, D. N., A. R. McCarthy, E. E. Doolin, S. J. Lacy-Hulbert, M. W. Woolford, and B. M. Buddle. 2004. Effect of recombinant cytokines on leucocytes and physiological changes in bovine mammary glands during early involution. J. Dairy Res. 71:154-161.

Wen, Z.-S., Y.-L. Xu, X.-T. Zou, and Z.-R. Xu. 2011. Chitosan nanoparticles act as an adjuvant to promote both Th1 and Th2 immune responses induced by ovalbumin in mice. Mar. Drugs 9:1038-1055. https://doi.org/10.3390/md9061038.

Whist, A. C., O. Østerås, and L. Sølverød. 2006. Clinical mastitis in Norwegian herds after a combined selective dry-cow therapy and teat-dipping trial. J. Dairy Sci. 89:4649-4659. https://doi org/10.3168/jds.S0022-0302(06)72515-2.

Yates, A., W. Akanni, M. R. Amode, D. Barrell, K. Billis, D. Carvalho-Silva, C. Cummins, P. Clapham, S. Fitzgerald, L. Gil, C. G. Girón, L. Gordon, T. Hourlier, S. E. Hunt, S. H. Janacek, N. Johnson, T. Juettemann, S. Keenan, I. Lavidas, F. J. Martin, T. Maurel, W. McLaren, D. N. Murphy, R. Nag, M. Nuhn, A. Parker M. Patricio, M. Pignatelli, M. Rahtz, H. S. Riat, D. Sheppard, K. Taylor, A. Thormann, A. Vullo, S. P. Wilder, A. Zadissa, E. Birney, J. Harrow, M. Muffato, E. Perry, M. Ruffier, G. Spudich, S. J. Trevanion, F. Cunningham, B. L. Aken, D. R. Zerbino, and P. Flicek. 2016. Ensembl 2016. Nucleic Acids Res. 44:D710-D716. https://doi.org/10.1093/nar/gkv1157.

Yeh, T.-H., L.-W. Hsu, M. T. Tseng, P.-L. Lee, K. Sonjae, Y.-C. Ho, and H.-W. Sung. 2011. Mechanism and consequence of chitosanmediated reversible epithelial tight junction opening. Biomaterials 32:6164-6173. https://doi.org/10.1016/j.biomaterials.2011.03.056. 